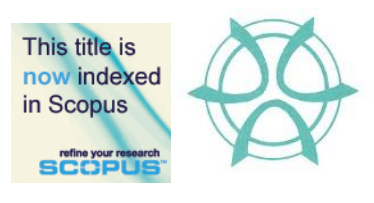

PLANNING MALAYSIA:

Journal of the Malaysian Institute of Planners

VOLUME 16 ISSUE 3 (2018) Page 132 - 142

\title{
POST OCCUPANCY EVALUATION MODEL: ADAPTIVE MEASURE TOWARDS SUSTAINABLE NEIGHBORHOOD DEVELOPMENT
}

\author{
Rostam Yaman ${ }^{1}$, Suwattana Thadaniti ${ }^{2}$, Noraini Ahmad ${ }^{3}$, Jamalunlaili Abdullah ${ }^{4}$, \\ \& Farrah Zuhaira Ismail ${ }^{5}$ \\ ${ }^{1,2}$ Environment Research Institute \\ CHULALONGKORN UNIVERSITY, THAILAND \\ ${ }^{3}$ Kulliyah of Architecture and Environmental Design \\ INTERNATIONAL ISLAMIC UNIVERSITY, MALAYSIA \\ 1,4,5Faculty Architecture, Planning and Surveying \\ UNIVERSITI TEKNOLOGI MARA, MALAYSIA
}

\begin{abstract}
Sustainable development is key to the strategic sustainability within a society. Sustainable neighbourhood development (SND) is a fundamental element of a sustainable community. However, SND on it own will certainly not permit all stakeholders, particularly the end-users, to efficiently address current or projected future issues that positioned beyond the extent of physical development scope. Thus, this research aims to explore whether pre-occupancy assessment criteria addresses the adaptive measures of sustainable dimension pillars (SDP) upon post-occupancy holistically. The research objective is to identify the post-occupancy sustainable criteria gap of SND. To achieve this, the research applied Stakeholders-Inclusion Approach using Post-Occupancy Evaluation Model (POEM) Handbook as measurement tool. This research seeks to measure and identify SDP gap on economic, social and environmental balance and responsive approach towards incremental improvements in SND at community and individual levels. The findings indicated that there are SDP adaptation gaps in post-occupied SND.
\end{abstract}

Keywords: post-occupancy evaluation, sustainable dimension pillar, assessment criteria, stakeholder-inclusion approach sustainable neighbourhood development 
PLANNING MALAYSIA

Journal of the Malaysia Institute of Planners (2018)

\section{INTRODUCTION}

\section{ASEAN Scenarios}

Since the 1950's, ASEAN region has experienced tremendous levels of urbanization with more than 1,000\% increase in urbanisation (Dahiya, 2014). The expansion of city-based economic activities draws human into urban areas and consequently expanding demand for more urban expansion and natural resources consumption. Thus, the urbanization process in the ASEAN region is inextricably linked to economic growth through (rapidly) rising consumption (Dahiya, 2016). This striking rise in the "urban power of consumption" gives impacts at multiple levels. Firstly, it raises the city-based demand for consumable goods and services. Secondly, it increases demand for developed land for residential, commercial, institutional, and other public uses (e.g. transport), along with a plethora of urban infrastructure and basic services. Thirdly, the demand for city expansion at the urban periphery causes an irreversible change in land-use - from agriculture and forests to urban built-up areas - with consequential concerns related to food in-security. Finally, it is quite likely that such a staggering expansion of a "consuming class" spurs demand for private vehicles, which creates an enormous increase in greenhouse gas emissions, with the potential of further exacerbating climate change and its worldwide impacts.

The global greenhouse gas emission statistics by sectors suggests the main emitted gas is carbon dioxide, which made up $70 \%$ of total emission (Rauland \& Newman, 2015). The main sectors of carbon emission which come from energy and land use manifest in urban development and urban lifestyle (Davies, 2016). Hence, the need to remodel the way of urbanizations either development or lifestyle towards reducing greenhouse gas emission (Ho, Matsuoka, Simson, \& Gomi, 2013).

\section{Urban Development \& GBC's/GBI's.}

Developing an economically productive urban set-up and at the same time sustainable and equally liveable is a world issue. Future projections by 2030 suggest the planet will be a global city and not regarded as global village as previously presumed (Yaman, 2016). Cities and metropolis will be the hub of economic activity and productivity, a centre for human livelihood and economic development. The neighbourhood roles in sustainable cities and as ways to address the UN Sustainable Development Goal No. 11: Make cities and human settlements inclusive, safe, resilient and sustainable, could be achieved via interconnected network of green spaces that helps stop the loss of biodiversity, enabling ecosystems to deliver their many services to people and nature and multiple health benefits (Haase et al., 2017). Urban development should be planned at district or micro level with requiring measurement and benchmark for 
Rostam Yaman, Suwattana Thadaniti, Noraini Ahmad, Jamalunlaili Abdullah, Farrah Zuhaira Ismail Post Occupancy Evaluation Model: Adaptive Measure Towards Sustainable Neighborhood Development

it performances. It should be both viable economically and sustainable environmentally, and also socially just.

The concept of greening the neighbourhoods, districts and finally the cities has become momentous challenge. Understanding the criteria frameworks that was learnt from greening the buildings is rightly essential. The ideal green district should emphasize on putting the pedestrian at the centre of planning and designed considerations, while vehicular is regarded as secondary factor (Aghaabbasi, Moeinaddini, Shah, \& Asadi-Shekari, 2017). Emphasizing communal walking and cycling distance to access daily need and socially interact is sustainable, the usage of energy is reduced, thus, no greenhouse gas (GHG) emitted to the atmosphere. Community can be connected to nature by accessing to green lungs, such as parks, gardens or playfields. The well-being of the communities is increased through employment and education opportunities within local vicinity, civics engagement and other local amenities (Peters, 2016).

Throughout the region, governments, developers and communities have realized the values of sustainable development, effort need to be consolidated into actions as holistic approach in sustainable built environment, community and economic is rather complex (McGill, Oyedele, McAllister, \& Qin, 2016). Green Building Councils/Institutes (GBC's/GBI's) in the ASEAN have recognized the needs of frameworks for sustainable communities, various rating assessment criteria's and tools for sustainable development have been developed and consistently revised. These frameworks have been developed to give clear and consistent direction on sustainable communities. They also act as reference to local authorities with a policy framework, project planning and approval, and for ultimate sustainable development outcomes (Palmqvist, 2015). However, most of the GBC's/GBI's in this region are still lacking on evaluation tools targeting at end-users or households, except Malaysia, Singapore and Indonesia (Table 1), which have pre-occupancy assessment tools (Yaman, Thadaniti, Suntornvongsagul, Adnan, \& Ahmad, 2017).

\section{MATERIAL AND METHODS}

\section{The Case Study}

The case study of this research is certified SND located in the Greater Kuala Lumpur, Malaysia (Figure 1). The certified SND theme is 'the promise of beauty, luxury, nature'. It is an integrated township development in the prime vicinity of Shah Alam, within Greater Kuala Lumpur. This premium urban neighbourhood township development comprises Commercial Centre, 2 phases of landed neighbourhood residences and 2 phases of condominium developments. The green township development plot spread across 60 acres of a freehold prime land. It exudes all the luxury and exclusivity and it is also the first green township in Malaysia that has revolutionized the land-use change of an industrial area into 
landscape paradise-like neighbourhood enclave in Shah Alam.

Table 1: Pre-occupancy certification and POEM implementation of SND in the ASEAN region

\begin{tabular}{|c|c|c|c|c|c|}
\hline \multirow[t]{2}{*}{ Country } & \multicolumn{2}{|c|}{ Pre-Occupancy } & \multicolumn{2}{|c|}{ Post-Occupancy } & \multirow[t]{2}{*}{ Remarks } \\
\hline & $\begin{array}{l}\text { Assess. } \\
\text { Criteria }\end{array}$ & $\begin{array}{c}\text { SND } \\
\text { Certification }\end{array}$ & $\begin{array}{l}\text { Assess. } \\
\text { Criteria }\end{array}$ & $\begin{array}{c}\text { Test \& } \\
\text { Evaluation }\end{array}$ & \\
\hline Malaysia & GBI & 8 Townships & POEM & 3 Townships & Launch in \\
\hline Institution: & Township & /neighbourhoods & for SND & /neighbourhoods & 2011 \\
\hline MGBC & $\begin{array}{l}\text { Assessment } \\
\text { Criteria }\end{array}$ & - & & - & $\begin{array}{l}\text { GBI-TAC } \\
\text { Version } 1.0\end{array}$ \\
\hline $\begin{array}{l}\text { Thailand } \\
\text { Institution: } \\
\text { TGBI }\end{array}$ & $\begin{array}{l}\text {-Not } \\
\text { Available }\end{array}$ & -Not Available & $\begin{array}{l}\text { POEM } \\
\text { for SND }\end{array}$ & $\begin{array}{l}1 \text { Township / } \\
\text { neighbourhood } \\
\text { - Parinyada } \\
\text { Village, } \\
\text { Bangkok }\end{array}$ & $\begin{array}{l}\text { NO rating } \\
\text { criteria for } \\
\text { Townships / }\end{array}$ \\
\hline $\begin{array}{l}\text { Singapore } \\
\text { Institution: } \\
\text { SGBC) }\end{array}$ & $\begin{array}{l}\text { Greenmark } \\
\text { for Districts } \\
\text { V2.0 }\end{array}$ & $\begin{array}{l}4 \text { Government } \\
\text { Land Sales Sites }\end{array}$ & $\begin{array}{l}\text {-Not } \\
\text { Available }\end{array}$ & -Not Available & $\begin{array}{l}\text { Launch in } \\
2009 \text {, GM for } \\
\text { Districts } \\
\text { Version } 2.0\end{array}$ \\
\hline $\begin{array}{l}\text { Indonesia } \\
\text { Institution: } \\
\text { (GBC } \\
\text { Indonesia }\end{array}$ & $\begin{array}{l}\text { Greenship } \\
\text { Neighborhood }\end{array}$ & -Not Available & $\begin{array}{l}- \text { Not } \\
\text { Available }\end{array}$ & -Not Available & $\begin{array}{l}\text { Green } \\
\text { Neighborhood } \\
\text { Tools - but } \\
\text { no data on } \\
\text { certification }\end{array}$ \\
\hline $\begin{array}{l}\text { Vietnam } \\
\text { Institution: } \\
\text { VGBC }\end{array}$ & $\begin{array}{l}\text {-Not } \\
\text { Available }\end{array}$ & -Not Available & $\begin{array}{l}\text {-Not } \\
\text { Available }\end{array}$ & -Not Available & $\begin{array}{l}\text { NO rating } \\
\text { criteria for } \\
\text { Townships }\end{array}$ \\
\hline $\begin{array}{l}\text { Philippines } \\
\text { Institution: } \\
\text { PHILGBC } \\
\end{array}$ & $\begin{array}{l}\text {-Not } \\
\text { Available }\end{array}$ & -Not Available & $\begin{array}{l}- \text { Not } \\
\text { Available }\end{array}$ & -Not Available & $\begin{array}{l}\text { NO rating } \\
\text { criteria for } \\
\text { Townships }\end{array}$ \\
\hline $\begin{array}{l}\text { Cambodia } \\
\text { Institution: } \\
\text { CamGBC }\end{array}$ & $\begin{array}{l}\text {-Not } \\
\text { Available }\end{array}$ & -Not Available & $\begin{array}{l}\text {-Not } \\
\text { Available }\end{array}$ & -Not Available & $\begin{array}{l}\text { NO rating } \\
\text { criteria for } \\
\text { Townships }\end{array}$ \\
\hline $\begin{array}{l}\text { Laos } \\
\text { Institution: } \\
\text { No data }\end{array}$ & $\begin{array}{l}\text {-Not } \\
\text { Available }\end{array}$ & -Not Available & $\begin{array}{l}\text {-Not } \\
\text { Available }\end{array}$ & -Not Available & $\begin{array}{l}\text { NO rating } \\
\text { criteria for } \\
\text { Townships }\end{array}$ \\
\hline $\begin{array}{l}\text { Myanmar } \\
\text { Institution: } \\
\text { No data }\end{array}$ & $\begin{array}{l}\text {-Not } \\
\text { Available }\end{array}$ & -Not Available & $\begin{array}{l}\text {-Not } \\
\text { Available }\end{array}$ & -Not Available & $\begin{array}{l}\text { NO rating } \\
\text { criteria for } \\
\text { Townships }\end{array}$ \\
\hline $\begin{array}{l}\text { Brunei } \\
\text { Institution: } \\
\text { GBC } \\
\text { Brunei }\end{array}$ & $\begin{array}{l}\text {-Not } \\
\text { Available }\end{array}$ & -Not Available & $\begin{array}{l}\text {-Not } \\
\text { Available }\end{array}$ & -Not Available & $\begin{array}{l}\text { NO rating } \\
\text { criteria for } \\
\text { Townships }\end{array}$ \\
\hline
\end{tabular}




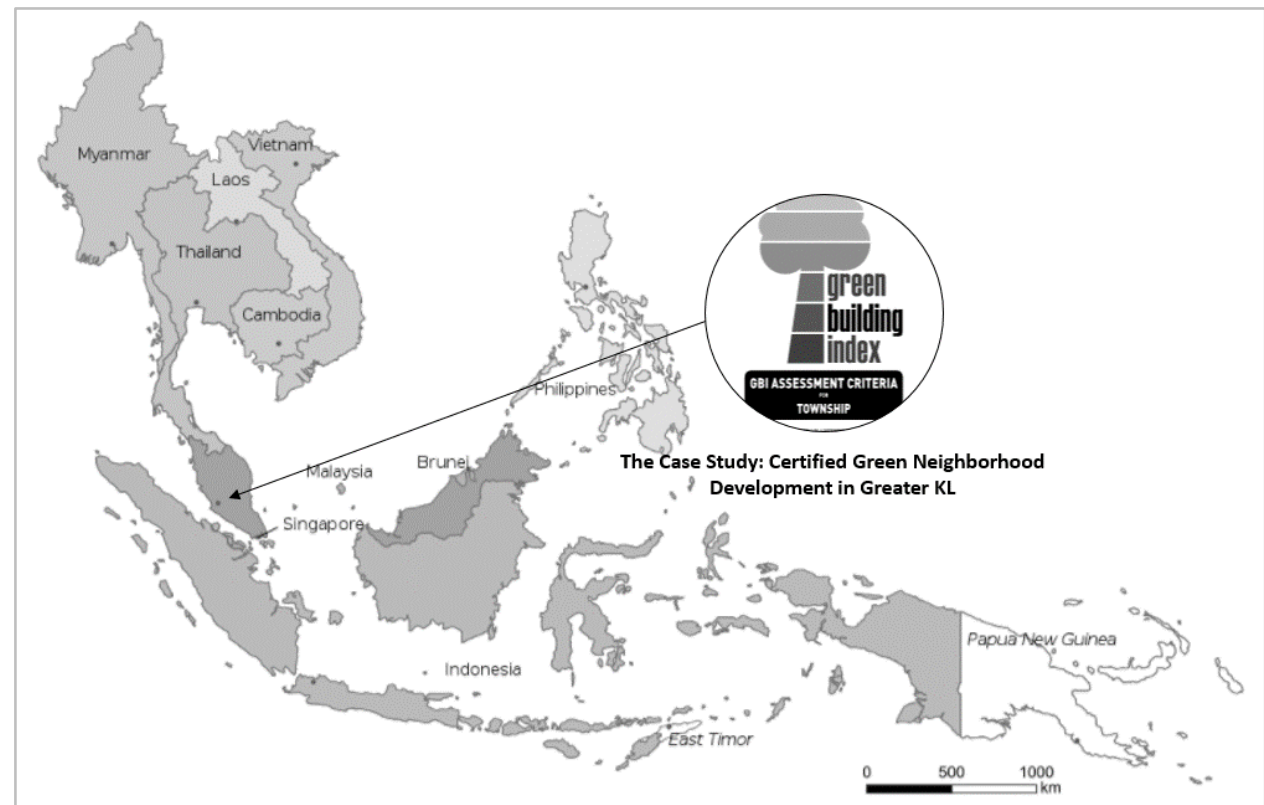

Figure 1: The case study - Green neighborhood development in Greater KL. Source: ASEAN Map by Wikinews; GBI Township by GBI Malaysia

\section{Research Methodology}

The stakeholder-inclusion approached was used in this research in order to gather end-user experience regarding the proposed POEM for Sustainable Neighborhood Development (SND) in ASEAN region. Figure 2 explains the research conceptual framework throughout the study.

POEM Procedures outlines the purpose and process from the perspective of an end-users/households undertaking evaluation process. POEM procedures were developed to find out end-user/household evaluation of SND and its criteria that took place at least a minimum 1 year after occupancy (Yaman, Adnan, Ismail, $\&$ Ahmad, 2015). The methodology outlined in POEM Evaluation Guideline was developed as a systematic approach to compare certified neighbourhood outcomes against vision outcomes. The purpose of a POEM Evaluation is to review certified SND outcomes against vision outcomes; disseminate awareness to end-users/households and to inform future review decisions/actions. The POEM process began with identifying the selected case study and the content analysis. Responses from the targeted households of the case study area were collected via questionnaires. The data was then analysed and compared with the case studies pre-occupancy score achieved as baseline. The application of POEM evaluation process may improve the assessment and certification of future sustainable neighbourhood development projects (Figure 3). 


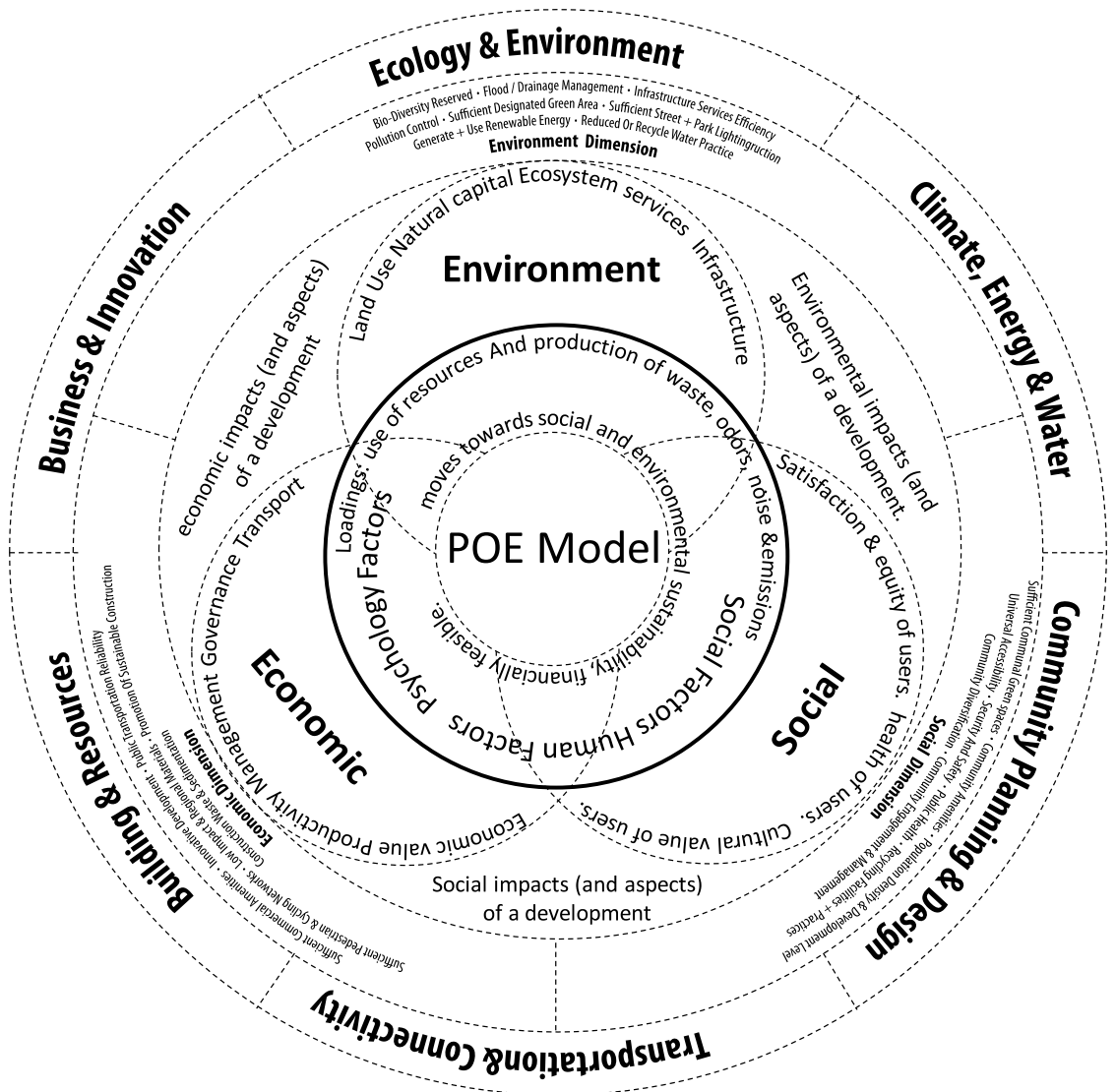

Figure 2: POEM conceptual model Source: Author, 2017

\section{FINDINGS AND DISCUSSION}

As shown in Table 2, the POEM evaluation criteria was categorized into three category, where each pillar consists of 8 evaluation sub-criteria (Environment Dimension Pillar: EnP Q1- EnP Q8; Social Dimension Pillar - SoP Q1- SoP Q8; Economic Dimension Pillar - EcP Q1- EcP Q8).

The results show that one environment sub-criteria, EnP Q5 BioDiversity Reserved Availability, scored low at 184/610. Meanwhile, EnP Flood/Drainage Clogging Experience Q6 scored below 50\% or failed to fulfill POEM evaluation criteria (304/610). The rest of the environment sub-criteria achieved certified score or 60\% (305/610 to 396.5/610) of POEM Evaluation criteria, but none of the environment sub-criteria scored above the certified score.

This study argues that there was low consideration (based on EnP Q5 and EnP Q6 score) to the importance of bio-diversity and flood/drainage systems. 
Rostam Yaman, Suwattana Thadaniti, Noraini Ahmad, Jamalunlaili Abdullah, Farrah Zuhaira Ismail Post Occupancy Evaluation Model: Adaptive Measure Towards Sustainable Neighborhood Development

Although these sub criteria represent high significance in Environment Dimension Pillar, there has been low awareness by the developers in conserving or preserving bio-diversity and eco-system. This POEM evaluation also found out that there was still gap in improving green area, efficient public lighting, efficient energy \& water practice and pollution control.

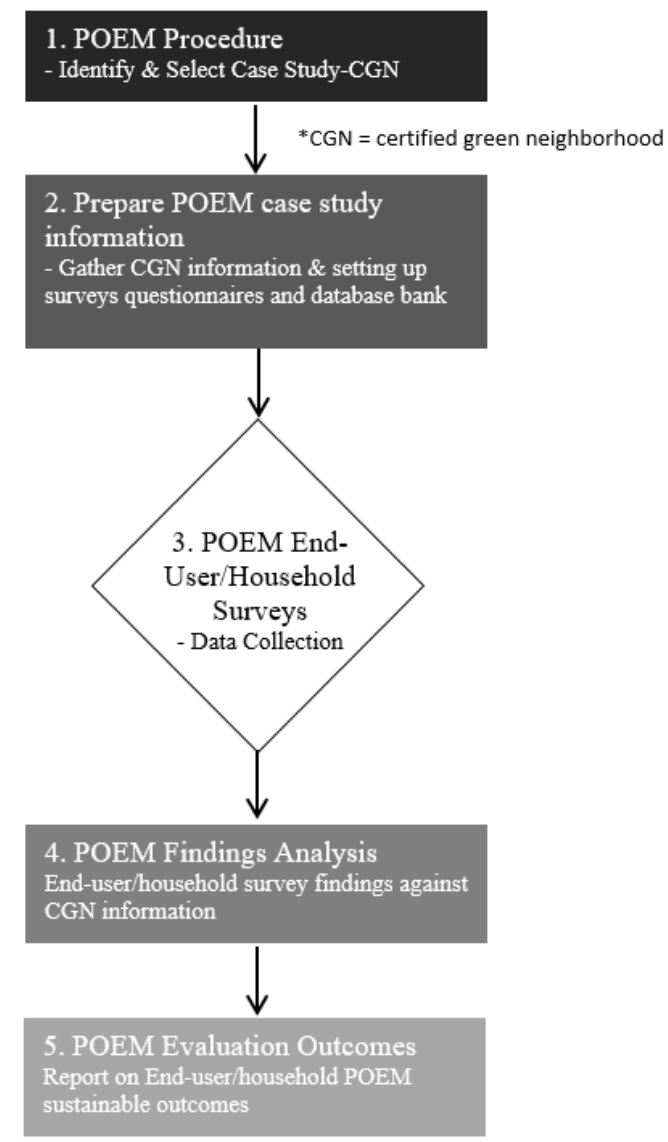

Figure 3. POEM Handbook procedures, evaluation criteria \& rating benchmark. Source: Author, 2017

For social dimension evaluation, none of the sub-criteria scored below $50 \%$ or failed to fulfilled POEM evaluation criteria. Most of the score for Social Dimension Pillar was within certified score or $60 \%$ (305/610 to 396.5/610) of POEM Evaluation criteria. There were three sub-criteria in Social Dimension Pillar that scored above certified score. These were SoP Q2 Population Density \& Development Level (410/610), SoP Q6 Recycling Facilities or Practice (357/610) and SoP Q7 Community Diversification (401/610). 
PLANNING MALAYSIA

Journal of the Malaysia Institute of Planners (2018)

Table 2: POEM Total Dimension Score of the Case Study

\begin{tabular}{|c|c|c|c|c|}
\hline \multicolumn{5}{|c|}{ POEM Scoring Calculation Master Sheet. } \\
\hline $\begin{array}{l}\text { Q_ } \\
\text { No }\end{array}$ & $\begin{array}{l}\text { Criteria } \\
\text { Coding }\end{array}$ & POEM Evaluation Criteria & $\begin{array}{l}\text { Available } \\
\text { Credits }\end{array}$ & $\begin{array}{l}\text { Scored } \\
\text { Credits }\end{array}$ \\
\hline \multicolumn{3}{|c|}{ Environment Dimension Pillar } & $\mathrm{Av}-\mathrm{Cr}$ & $\mathrm{Sc}-\mathrm{Cr}$ \\
\hline 1 & EnP Q1 & Sufficient Designated Green Area & 610 & 311 \\
\hline 2 & EnP Q2 & Sufficient Street Or Park Lighting & 610 & 316 \\
\hline 3 & EnP Q3 & Generate Or Use Renewable Energy & 610 & 315 \\
\hline 4 & EnP Q4 & Reduced Or Recycle Water Practice & 610 & 319 \\
\hline 5 & EnP Q5 & Bio-Diversity Reserved Availability & 610 & 184 \\
\hline 6 & EnP Q6 & Flood / Drainage Clogging Experience & 610 & 304 \\
\hline 7 & EnP Q7 & Infrastructure Services Efficiency & 610 & 368 \\
\hline \multirow[t]{3}{*}{8} & EnP Q8 & Pollution Control \& Experience & 610 & 307 \\
\hline & & Dimension Av-Cr/ Sc-Cr & 4880 & 2424 \\
\hline & \multicolumn{2}{|r|}{ EnP Dimension Scored Achieved } & & $49.6 \%$ \\
\hline \multicolumn{3}{|c|}{ Social Dimension Pillar } & $\mathrm{Av}-\mathrm{Cr}$ & $\mathrm{Sc}-\mathrm{Cr}$ \\
\hline 1 & SoP Q1 & Sufficient Communal Greenspaces & 610 & 371 \\
\hline 2 & SoP Q2 & Population Density \& Development Level & 610 & 410 \\
\hline 3 & SoP Q3 & Universal Accessibility Availability & 610 & 382 \\
\hline 4 & SoP Q4 & Security And Safety Experience & 610 & 326 \\
\hline 5 & SoP Q5 & Public Health Concerns & 610 & 407 \\
\hline 6 & SoP Q6 & Recycling Facilities Or Practices & 610 & 357 \\
\hline 7 & SoP Q7 & Community Diversification & 610 & 401 \\
\hline \multirow[t]{3}{*}{8} & SoP Q8 & Community Engagement \& Management & 610 & 365 \\
\hline & & Dimension Av-Cr/Sc-Cr & 4880 & 3019 \\
\hline & \multicolumn{2}{|r|}{ SoP Dimension Scored Achieved } & & $61.8 \%$ \\
\hline \multicolumn{3}{|c|}{ Economic Dimension Pillar } & $\mathrm{Av}-\mathrm{Cr}$ & $\mathrm{Sc}-\mathrm{Cr}$ \\
\hline 1 & EcP Q1 & Distance To Community Amenities & 610 & 317 \\
\hline 2 & EcP Q2 & Public Transport Reliability & 610 & 321 \\
\hline 3 & EcP Q3 & Sufficient Pedestrian \& Cycling Networks & 610 & 317 \\
\hline 4 & EcP Q4 & Low Impact \& Regional Materials & 610 & 210 \\
\hline 5 & EcP Q5 & Promotion Of Sustainable Construction & 610 & 315 \\
\hline 6 & EcP Q6 & Construction Waste \& Sedimentation & 610 & 261 \\
\hline 7 & EcP Q7 & Sufficient Commercial Amenities & 610 & 395 \\
\hline \multirow[t]{6}{*}{8} & EcP Q8 & Innovative Development & 610 & 368 \\
\hline & \multirow{2}{*}{\multicolumn{3}{|c|}{$\begin{array}{r}\text { Dimension Av-Cr/Sc-Cr } \\
\text { EcP Dimension Scored Achieved }\end{array}$}} & 2504 \\
\hline & & & & $51.3 \%$ \\
\hline & & Total Dimension Av-Cr / Sc-Cr & 14,640 & 7947 \\
\hline & \multicolumn{3}{|c|}{ Sc-Cr (72) / Av-Cr (120) x Weighting (100\%) } & $54.2 \%$ \\
\hline & & Total Dimension Scored Achieved & & 54 \\
\hline
\end{tabular}

Based on the end-users/households opinion for Social Dimension Pillar, the overall sub-criteria scored credit achieved was considered good or achieved since the neighbourhood was awarded with 'Certified' certification by GBI Malaysia for sustainable township. In this POEM evaluation, the findings 
Rostam Yaman, Suwattana Thadaniti, Noraini Ahmad, Jamalunlaili Abdullah, Farrah Zuhaira Ismail Post Occupancy Evaluation Model: Adaptive Measure Towards Sustainable Neighborhood Development

suggested that improvement can still be made on security and safety of the neighbourhood (based on SoP Q4 lowest score). Additionally, the score of SoP Q6 also suggests that this certified neighbourhood may need a bit more extra effort in improving recycling facilities and practices by the community of the neighbourhood.

Regarding the economic dimension aspects, majority POEM evaluation criteria fulfilled the certified score or 60\% (305/610 to 396.5/610) except two. None of evaluation sub-criteria in Economic Dimension Pillar was above the certified score. The two sub-criteria that scored below 50\% (below 305/610) or failed to fulfilled POEM evaluation criteria were EcP Q4 Low Impact \& Regional Materials (256/610) and EcP Q6 Construction waste \& Sedimentation (261/610).

Based on the POEM evaluation, the overall economic dimension subcriteria scored credit achieved was considered 'achieved'. The exception was EcP Q4 where this criteria was below 'Certified' score, suggesting lacking in optimizing low impact and regional materials in this certified sustainable. Similarly, EcP Q6 score suggests lacking in effort in Construction Waste \& Sedimentation. The practical features of 'Australian' louvered windows which allow controllable continuous air flow cross the internal space mentioned in this Neighborhood Pre-Occupancy Sustainable features is the example of out-bound or non-regional materials which was used in this development. Other measures that can be stressed in promoting sustainable economic dimension are further considerations on sustainable transportation \& connectivity; and sustainable materials \& resources. More efforts can be further highlighted in transportation \& connectivity by improving pedestrian and cycling networks and more awareness on materials and resources by promoting construction waste management \& sustainable construction.

The overall POEM findings, for this case study was rated as 'Certified' where the total POEM score was 54, the overall dimensions scored credit achieved was considered 'low achieved' since this neighbourhood was also awarded with 'Certified' (50-65 score achieved) certification by GBI Malaysia for sustainable township. This indicates that this case study's post-occupancy score is similar to what it has achieved during planning and completion or during pre-occupancy assessments.

\section{CONCLUSION}

POEM evaluation on-site testing of the certified sustainable neighbourhood case study have presented diverse narratives of how sustainable urban neighbourhood I township development has been developed in the Greater KL in the last half decades. The results derived from the previous on-site study pointed out that the selected certified SND have resulted in a rather lower dimension score achieved in post-occupancy evaluation based on end-users/households opinion compared to pre-occupancy evaluation criteria during planning assessment or completion 
and verification assessment of SND. The obtained results have established that the certified SND has been evaluated with an adaptation gap and recognition of the three dimensions of the proposed POEM that include different SDP aspects. The difference in score between post- and pre-occupancy evaluation was due to design and planning envisaged functionality were slightly dissimilar from endusers/households perception on the occupied space.

The findings indicate that a comprehensive Stakeholder-Inclusion Approach method in developing POEM for SND (Figure 2), supported by key issues of SDP understanding in sustainability neighbourhood development and guided by clear and comprehensive POEM procedures, can oversee and foster the SND and its communities towards an enhanced, balanced and holistic sustainability in the Greater KL. The results generated in this study have verified that the function and significance of post-occupancy evaluation has become as one of the important issues that should be taken into consideration by the related institutions or authorities in charge for the urban development and community well-being in the urban area. Pre-occupancy sustainable assessment may lay the foundation for the vision of sustainable goals but the sustainable post-occupancy evaluation is the actual measure in rating the sustainability level as it is based on the actual physical built environment instead of on drawings on papers, the actors are real as it engaged all related stakeholders instead of projected statistical numbers of occupants, and finally it also considers the local context of culture, customs and religions.

Thus, this study claims that the adoption and implementation of POEM for SND in the Greater KL will facilitate efforts to enhance the sustainability of current and future urban neighbourhood development by delivering a clear interpretation of the present sustainable dimension of post-occupied development and providing insights towards the forthcoming progression in order to achieve the sustainable urban growth of Klang Valley/Greater KL. There is no doubt that pre-occupancy sustainable assessment criteria is necessary and served its purposes in sustainable urban development. However, the intent of POEM for SND is to further facilitate the continuation and improvement in sustainable urban development be it at individual, community, neighbourhood or township level, it is for betterment in sustainable agenda as whole.

\section{ACKNOWLEDGEMENT}

The author would like to acknowledge EDS, Chulalongkorn University, KAED, International Islamic University Malaysia and FSPU, Universiti Teknologi Mara for providing research platform and research grant. 
Rostam Yaman, Suwattana Thadaniti, Noraini Ahmad, Jamalunlaili Abdullah, Farrah Zuhaira Ismail Post Occupancy Evaluation Model: Adaptive Measure Towards Sustainable Neighborhood Development

\section{REFERENCES}

Aghaabbasi, M., Moeinaddini, M., Shah, M. Z., \& Asadi-Shekari, Z. (2017). A new assessment model to evaluate the microscale sidewalk design factors at the neighbourhood level. Journal of Transport \& Health, 5, 97-112.

Dahiya, B. (2014). Southeast Asia and sustainable urbanization. Global Asia, 9(3), 84 91.

Dahiya, B. (2016). ASEAN economic integration and sustainable urbanization. Journal of Urban Culture Research, 13(1), 8-15.

Davis, S. M. (2016). Rising temperatures, rising stakes: The role of international policy negotiations in the climate crisis (Student thesis). Fordham University, New York, USA.

Haase, D., Kabisch, S., Haase, A., Andersson, E., Banzhaf, E., Baró, F., ... \& Krellenberg, K. (2017). Greening cities-To be socially inclusive? About the alleged paradox of society and ecology in cities. Habitat International, 64, 41-48.

Ho, C. S., Matsuoka, Y., Simson, J., \& Gomi, K. (2013). Low carbon urban development strategy in Malaysia-The case of Iskandar Malaysia development corridor. Habitat International, 37, 43-51.

McGill, G., Oyedele, L. O., McAllister, K., \& Qin, M. (2016). Effective indoor air quality for energy-efficient homes: A comparison of UK rating systems. Architectural Science Review, 59(2), 159-173.

Palmqvist, T. (2015). An assessment of sustainable development work in Swedish municipalities (Master thesis). Uppsala University, Sweden.

Peters, T. (2016). Social sustainability in context: Rediscovering Ingrid Gehl's Bomiljø. Architectural Research Quarterly, 20(4), 371-380.

Rauland, V., \& Newman, P. (2015). Decarbonising cities: Mainstreaming low carbon urban development. New York: Springer.

Yaman, R., Adnan, H., Ismail, F. Z., \& Ahmad, N. (2015). Sustainable management (SM) guide in GBI interiors design project tools. ARPN Journal of Engineering and Applied Sciences, 10(10), 4498-4507.

Yaman, R., Thadaniti, S., Suntornvongsagul, K., Adnan, H., \& Ahmad, N. (2017). Post occupancy evaluation for sustainable neighborhood development. Advanced Science Letters, 23(4), 3128-3131.

Yaman, R. (2016). A post occupancy evaluation model for sustainable urban neighborhood assessment in Malaysia (Doctorate dissertation). Chulalongkorn University, Thailand. 